\title{
BMJ Open Realist synthesis of educational interventions to improve nutrition care competencies and delivery by doctors and other healthcare professionals
}

\author{
Victor Mogre, ${ }^{1,2}$ Albert J J A Scherpbier, ${ }^{2}$ Fred Stevens,, ${ }^{2}$ Paul Aryee, ${ }^{3}$ \\ Mary Gemma Cherry, ${ }^{4}$ Tim Dornan ${ }^{2}$
}

To cite: Mogre V, Scherpbier AJJA, Stevens F, et al. Realist synthesis of educational interventions to improve nutrition care competencies and delivery by doctors and other healthcare professionals. BMJ Open 2016:6:e010084. doi:10.1136/bmjopen-2015010084

- Prepublication history and additional material is available. To view please visit the journal (http://dx.doi.org/ 10.1136/bmjopen-2015010084).

Received 23 September 2015 Revised 18 July 2016 Accepted 29 July 2016

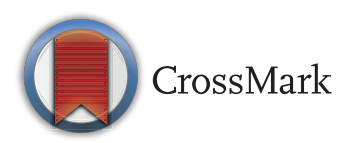

For numbered affiliations see end of article.

Correspondence to Mr Victor Mogre; vmogre@uds.edu.gh

\section{ABSTRACT}

Objective: To determine what, how, for whom, why, and in what circumstances educational interventions improve the delivery of nutrition care by doctors and other healthcare professionals work.

Design: Realist synthesis following a published protocol and reported following Realist and Metanarrative Evidence Synthesis: Evolving Standards (RAMESES) guidelines. A multidisciplinary team searched MEDLINE, CINAHL, ERIC, EMBASE, PsyINFO, Sociological Abstracts, Web of Science, Google Scholar and Science Direct for published and unpublished (grey) literature. The team identified studies with varied designs; appraised their ability to answer the review question; identified relationships between contexts, mechanisms and outcomes (CMOs); and entered them into a spreadsheet configured for the purpose. The final synthesis identified commonalities across CMO configurations.

Results: Over half of the 46 studies from which we extracted data originated from the USA. Interventions that improved the delivery of nutrition care improved skills and attitudes rather than just knowledge; provided opportunities for superiors to model nutrition care; removed barriers to nutrition care in health systems; provided participants with local, practically relevant tools and messages; and incorporated nontraditional, innovative teaching strategies. Operating in contexts where student and qualified healthcare professionals provided nutrition care in developed and developing countries, these interventions yielded health outcomes by triggering a range of mechanisms, which included feeling competent, feeling confident and comfortable, having greater self-efficacy, being less inhibited by barriers in healthcare systems and feeling that nutrition care was accepted and recognised.

Conclusions: These findings show how important it is to move education for nutrition care beyond the simple acquisition of knowledge. They show how educational interventions embedded within systems of healthcare can improve patients' health by helping health students and professionals to appreciate the importance of delivering nutrition care and feel competent to deliver it.
Strengths and limitations of this study

- Application of the principles of realist synthesis to nutrition and education research is novel.

- The characteristics and conditions of educational interventions that can improve the delivery of nutrition care, identified by this review, are important to the work of policymakers, researchers, health professions educators and course developers.

- Few reports of failed educational interventions were found, indicating a risk of positive publication bias.

- Until our conceptual model is tested and refined in the real world, we consider it to be an indefinite candidate theory, presenting elements worth considering by those concerned with the design, implementation and evaluation of educational interventions to improve the delivery of nutrition care by doctors and other healthcare professionals.

- We cannot assume that the research evidence we identified represents 'real-world' practices, and therefore our claims for the transferability of this research must be guarded.

\section{INTRODUCTION}

Nutrition is an important component of healthcare. It plays a critical role in the prevention and treatment of most cardiovascular and cerebrovascular diseases, which are leading causes of morbidity and mortality throughout the world. ${ }^{1-3}$ Nutrition is even more important in sub-Saharan Africa because malnutrition is a major cause of morbidity and mortality, particularly among children. ${ }^{4}$

Several landmark reports ${ }^{5}$ have identified the delivery of nutrition care as one of the core responsibilities of doctors. Research has also shown that nutrition counselling delivered by them has positive influence on patients' clinical outcomes. They and other 
healthcare professionals whose primary role is not nutrition care, however, often miss opportunities to advise patients on diet and health. ${ }^{7}{ }^{8}$ Health workers in primary care settings are particularly important providers of nutrition care because they can motivate even healthy individuals to adopt healthier lifestyles. ${ }^{9}$ The care expected from primary care health workers includes nutrition assessment, education and counselling interventions, monitoring and evaluation. Lack of knowledge,${ }^{10}$ skills and confidence, ${ }^{11}{ }^{12}$ as well as negative attitudes towards delivery of nutrition care and low outcome expectancy, ${ }^{13}$ are barriers to healthcare professionals providing nutrition care. In addition to these individual-related factors, several system-related factors such as lack of time, office space, payment, materials and education ${ }^{14}$ also prevent the delivery of nutrition care by these healthcare professionals.

Many educational interventions have been designed and implemented to improve nutrition care, but their effects have been inconsistent and often weak. ${ }^{15-17}$ There remains a need, therefore, for interventions that can change healthcare professionals' behaviour in practice. ${ }^{15-17}$ It is imperative to identify contextual factors, which mediate or inhibit their competence and delivery of nutrition care. ${ }^{18}{ }^{19}$ In order to meet those needs, researchers have to identify components of effective educational interventions and processes.

To date, only one secondary research investigation has synthesised conclusions from existing evidence about nutrition care. ${ }^{20}$ The authors of that review concluded that in-service nutrition training improved healthcare professionals' knowledge, nutrition-related counselling skills and malnutrition management skills. The main limitation was that this was a traditional systematic review, which only considered in-service nutrition training programmes. Its authors found that the evidence base was very heterogeneous; studies had widely varying study designs with heterogeneous outcome measures; and there were wide differences in the competence, experience and backgrounds of participating healthcare professionals. As the authors acknowledged, systematic review methodology limited their ability to recognise and account for the complexity of interactions within such interventions.

We reasoned that we could move the field forward by conceptualising nutrition education interventions as complex ones within a realist research approach. As noted in our published review protocol, ${ }^{21}$ we recognised that educational interventions involve multiple actors operating at different levels with a range of artefacts in varied material environments. ${ }^{22}$ We assumed that these components operate in non-linear ways to yield contextdependent outcomes. Realist synthesis explores 'what is it about this intervention that works, for whom and in what circumstances?' and is therefore an appropriate way to study complex interventions. ${ }^{23}$ It is an iterative, theory-driven approach, which aims to unpack the theories that inform decisions and actions adopted in the design and implementation of interventions. ${ }^{24}$ Realist synthesis begins with the development of an initial programme (or candidate) theory about how interventions work, the contexts in which they do and do not work, and the differentiated patterns of outcomes that they generate. ${ }^{25}$ As the review progresses, researchers test the initial programme theory and refine it as more evidence becomes available. ${ }^{26}$

Thus, the aim of this realist review was to determine what, how, for whom, why and in what circumstances educational interventions improve the delivery of nutrition care by doctors and other healthcare professionals work.

\section{METHODS}

$\mathrm{VM}$ is a nutritionist working in sub-Saharan Africa, which provided a context for the research. Other members of the team included scholars of medical education, evidence synthesis, social science, nutrition and an experienced clinician.

\section{Alteration from protocol}

The review question above is broader than in the published protocol ${ }^{21}$ because the search showed important findings from research in health professions other than medicine, which the team felt could make a valuable contribution.

\section{Search methods}

Search terms pertaining to nutrition, care, healthcare professionals, training etc were scoped on two electronic databases. Resulting articles were reviewed, and refinement of search terms was not considered necessary. Further explanation and a full list of the search terms can be found in our published protocol. ${ }^{21}$ A search strategy was created for Ovid MEDLINE (available in online supplementary appendix 1) and adapted for the rest of the databases. These databases were CINAHL, ERIC, EMBASE, PsycINFO, Sociological Abstracts, Web of Science, Science Direct and Google Scholar, the latter of which was used to search for grey literature. Email alerts were set for journals and RSS feeds for databases to ensure that we identified new papers as soon as they became available.

\section{Inclusion criteria}

- Study participants: Medical students, students of other health professions and practising healthcare professionals (eg, nurses, physician assistant).

- Focus of intervention: Developing participants' competencies in any aspect of nutrition practice behaviour.

- Study design: All.

- Context of intervention: Medical schools, residency and fellowship programmes, and interventions at community and hospital settings.

- Publication language: English. 
- Publication date: January 1994 to December 2014 inclusive. This date range was chosen because preliminary searches indicated that educational interventions to improve nutrition care competencies and delivery among doctors and other healthcare professionals gained prominence within published literature around 1994.

\section{Exclusion criteria}

We sought to understand generalists' delivery of nutrition education, and therefore we excluded research that only considered the education of dietitians and/or nutritionists since nutrition is their main responsibility. While we excluded conference proceedings, opinion pieces, case studies and abstracts, we used them to develop the initial candidate theories reported in our protocol. $^{21}$ We also excluded systematic reviews, although they informed the design of our data extraction form and provided an insight into context, mechanism outcome (CMO) configurations and additional references. Papers were also excluded if they lacked evaluation or outcome data and not being about improvement in nutrition care competencies.

\section{Study selection}

Figure 1 shows the flow chart of the search and selection processes. The final search yielded 4500 hits. VM and TD initially screened the titles of 100 hits independently and compared their findings. There was almost complete agreement, and VM continued with the screening.

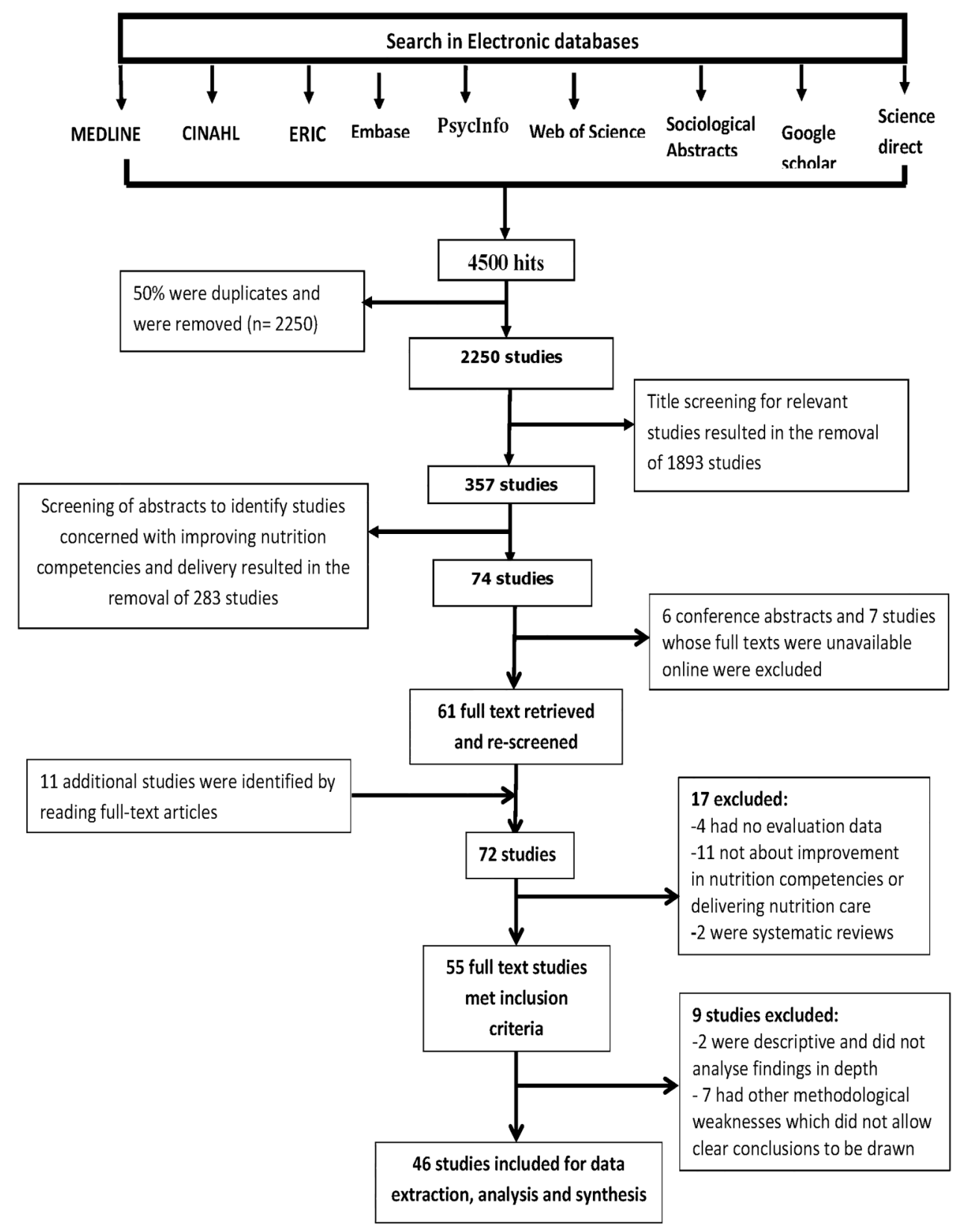

Figure 1 Search and selection process. 
After eliminating duplicates, 357 studies were selected. Having obtained their abstracts, VM, TD and MGC determined independently whether each study was concerned with improving nutrition care competencies and delivery of nutrition care. At a face-to-face discussion, we compared our choices, for which the $\kappa$ statistic of agreement was 0.9. This yielded 74 studies, 6 of which were excluded because they were conference abstracts. Seven studies could not be obtained despite repeated attempts. VM read the reference lists of the remaining 61 studies, and all identified systematic reviews, identifying 11 more studies.

\section{Quality assessment}

It is regarded as acceptable in realist synthesis to include part(s) or whole studies for analysis and synthesis, provided that the methods employed for collecting such data are robust. ${ }^{27}$ As recommended by Pawson, ${ }^{25}$ the appraisal of primary studies was informed by their relevance as well as their rigour. ${ }^{25}$ Our judgements of a study's relevance were informed by the extent to which the whole study or parts of it were relevant to our published initial programme theory. ${ }^{21}$ Our assessment of rigour was informed by the trustworthiness of studies' design, sample size and data collection tools in relation to the outcomes reported. The Mixed Methods Appraisal Tool $^{28}$ helped us assess rigour. ${ }^{28}$ Based on the exclusion and inclusion criteria, VM selected 55 of the 72 studies for quality assessment. Quality assessment was conducted by AS, TD, FS and MGC. This process resulted in the exclusion of nine studies from which clear conclusions could not be drawn because of methodological weaknesses. The remaining 46 studies were included into our data analysis. We kept notes of our reasons for including or excluding each study and resolved doubts about our judgements of study quality by discussing between ourselves. The processes of quality assessment and data extraction proceeded concurrently.

\section{Data extraction, analysis and synthesis}

For the purpose of data extraction, we followed guidance from previous related systematic reviews ${ }^{20} 22$ 29-31 and iteratively refined our procedures in accordance with the focus of the review. VM initially extracted data from a sample of 10 studies, discussed the findings with the other members of the team and used those discussions to guide further data extraction. Data extracted included the following:

- Study design, sample size and outcome data

- Educational levels of study participants (students vs practising health workers)

- How course material had been developed

- Topics covered

- Methods of teaching and learning

- Methods of evaluating outcomes including data collection tools

- Intervention type (eg, workshops, curriculum designs)

- Durations of intervention
- Contexts of intervention (eg, practising healthcare professionals, students)

- Mechanisms generated

- Learning outcomes

- Impacts (if any) of intervention on clinical outcomes

- Any theories or mechanisms postulated by author(s) explaining the effects of interventions

We read all 46 included studies twice, transferring relevant data into our data extraction form. We identified the CMOs and interactions between them for each study as well as the theory informing each intervention. To do that, we assumed that the design of each study was informed by a theory, which the authors stated explicitly or implicitly. Identifying those theories helped us understand how interventions worked to generate outcomes. We discussed and reflected on all the data we had identified for each study, sometimes using extracts of publication narratives to foster reflection.

The next stage was to identify themes that were common to different studies. Using an interpretative and narrative approach, we discussed and synthesised initial conclusions, which we used to refute or refine the candidate theories in our published protocol. $^{21} \mathrm{We}$ chose this process of synthesis in preference to a meta-analysis, which would not have been possible given the diversity in study populations, designs, interventions and outcomes. ${ }^{32}$

\section{RESULTS}

\section{General characteristics of the studies}

Table 1 provides a summary of the 46 studies. Twenty-seven (59\%) came from the USA, 7 (19\%) from Europe, 4 each from South America (all from Brazil) and Asia, 2 from Canada and 1 each from Africa (ie, South Africa) and Australia. In total, 4816 participants participated in them (median=76 participants; IQR: 47, 178). Interventions that had healthcare professionals as participants had somewhat larger numbers (median $=98$; IQR: 46, 163) than those having students as participants (median=54 participants; IQR: 32, 152).

The studies had varied study designs (shown in table 2) with a preponderance $(n=39,85 \%)$ of quasi-experimental designs. Twenty-one studies had follow-up evaluations after the pre-test and post-test evaluations. The time period between post-test and follow-up evaluations ranged between 2 weeks and 12 months.

Most studies ( $\mathrm{n}=32,70 \%)$ evaluated outcomes using surveys of knowledge, attitudes, self-reported practice behaviours, self-efficacy, confidence and feedback. A large proportion of these surveys were developed by the authors, who did not usually report the psychometric properties of their instruments. All the interventions that set out to improve knowledge used multiple-choice questions (ranging between 1 and 78 questions). Changes in attitude before and after interventions were 
Table 1 Summary of findings of studies reviewed $(n=46)$

\begin{tabular}{|c|c|c|c|c|c|c|}
\hline $\begin{array}{l}\text { Author(s) and } \\
\text { year }\end{array}$ & Intervention type & $\begin{array}{l}\text { Study } \\
\text { location }\end{array}$ & Participants & Study design & $\begin{array}{l}\text { Focus of intervention/topics } \\
\text { covered }\end{array}$ & Outcomes \\
\hline Levy et al, $2011^{33}$ & Workshop & USA & $\begin{array}{l}\text { Primary healthcare } \\
\text { professionals (doctors, } \\
\text { nurses, physician } \\
\text { assistants) }\end{array}$ & $\begin{array}{l}\text { Pre-test and } \\
\text { post-test without } \\
\text { control group }\end{array}$ & $\begin{array}{l}\text { Training programme to provide } \\
\text { information, tools and technical } \\
\text { assistance to primary care } \\
\text { practices to improve delivery of } \\
\text { preventive services and the } \\
\text { management of chronic diseases }\end{array}$ & $\begin{array}{l}\text { Training well received by all } \\
\text { participants } \\
\text { Self-reported improvement } \\
\text { in knowledge between } \\
\text { pre-test and post-test } \\
\text { Self-reported satisfaction } \\
\text { with intervention }\end{array}$ \\
\hline Carson, $2003^{34}$ & $\begin{array}{l}\text { Part of an } \\
\text { ambulatory clerkship }\end{array}$ & USA & $\begin{array}{l}\text { Fourth year medical } \\
\text { students }\end{array}$ & Cross-sectional & $\begin{array}{l}\text { Training medical students on } \\
\text { assessment of body composition } \\
\text { using tape measure } \\
\text { Facilitating the identification and } \\
\text { treatment of metabolic syndrome }\end{array}$ & $\begin{array}{l}\text { Increased self-reported } \\
\text { knowledge } \\
\text { Probable changes in } \\
\text { practice behaviour }\end{array}$ \\
\hline Taren et al, $2003^{35}$ & Required course & USA & $\begin{array}{l}\text { Preclinical medical } \\
\text { students }\end{array}$ & $\begin{array}{l}\text { Pre-test and } \\
\text { post-test with } \\
\text { control group }\end{array}$ & $\begin{array}{l}\text { Evaluation of an integrated } \\
\text { nutrition education programme } \\
\text { Nutrition intervention for disease } \\
\text { prevention and therapy }\end{array}$ & $\begin{array}{l}\text { Significant increase in } \\
\text { nutrition OSCE scores } \\
\text { between pre-test and } \\
\text { post-test } \\
\text { Increased self-reported } \\
\text { satisfaction in nutrition } \\
\text { content of the curriculum }\end{array}$ \\
\hline Buckley, $2003^{36}$ & $\begin{array}{l}\text { Varied formats } \\
\text { (web-based, } \\
\text { web-enhanced and } \\
\text { traditional lectures) }\end{array}$ & USA & $\begin{array}{l}\text { Fourth year nursing } \\
\text { students }\end{array}$ & Cross-sectional & $\begin{array}{l}\text { Evaluating the effect of various } \\
\text { formats of training on the nutrition } \\
\text { knowledge of participants }\end{array}$ & $\begin{array}{l}\text { No significant changes in } \\
\text { knowledge between the } \\
\text { three formats } \\
\text { More positive perception of } \\
\text { web-enhanced than the } \\
\text { web-based and traditional }\end{array}$ \\
\hline Ray et al, $2012^{37}$ & $\begin{array}{l}\text { Lectures, } \\
\text { demonstrations and } \\
\text { interactive practical } \\
\text { sessions }\end{array}$ & UK & $\begin{array}{l}\text { Third and fourth year } \\
\text { clinical students }\end{array}$ & $\begin{array}{l}\text { Pre-test and } \\
\text { post-test without } \\
\text { control group }\end{array}$ & $\begin{array}{l}\text { Evaluating the effectiveness of a } \\
\text { nutrition education intervention in a } \\
\text { cohort of tomorrow's doctors using } \\
\text { knowledge, attitude and practice } \\
\text { scores related to clinical nutrition } \\
\text { Covering topics relating to hospital } \\
\text { malnutrition }\end{array}$ & $\begin{array}{l}\text { Significant improvement in } \\
\text { knowledge scores between } \\
\text { pre-test and post-test } \\
\text { Significant changes in } \\
\text { attitude scores } \\
\text { Students reported } \\
\text { satisfaction with the course } \\
\text { Applied acquired knowledge } \\
\text { to patients }\end{array}$ \\
\hline Ke et al, $2008^{38}$ & Workshop & Taiwan & $\begin{array}{l}\text { Nurses in ICU, GI and } \\
\text { GS }\end{array}$ & $\mathrm{RCT}$ & $\begin{array}{l}\text { The effects of educational } \\
\text { intervention on nurses' knowledge, } \\
\text { attitudes and behavioural } \\
\text { intentions regarding supplying } \\
\text { artificial nutrition and hydration } \\
\text { Coverage of topics such as } \\
\text { normal nutrient metabolism, }\end{array}$ & $\begin{array}{l}\text { Significant improvement in } \\
\text { knowledge between pre-test } \\
\text { and post-test } \\
\text { Significant changes in mean } \\
\text { attitude scores } \\
\text { Significant changes in } \\
\text { behaviour intentions }\end{array}$ \\
\hline
\end{tabular}


Table 1 Continued

\begin{tabular}{|c|c|c|c|c|c|c|}
\hline $\begin{array}{l}\text { Author(s) and } \\
\text { year }\end{array}$ & Intervention type & $\begin{array}{l}\text { Study } \\
\text { location }\end{array}$ & Participants & Study design & $\begin{array}{l}\text { Focus of intervention/topics } \\
\text { covered }\end{array}$ & Outcomes \\
\hline $\begin{array}{l}\text { Ockene et al, } \\
1995^{43}\end{array}$ & Workshop & USA & Internists & RCT & $\begin{array}{l}\text { Impact of a training programme on } \\
\text { physicians' lipid intervention } \\
\text { knowledge, attitudes and skills } \\
\text { Improved skills on brief dietary risk } \\
\text { assessment and patient-centred } \\
\text { counselling }\end{array}$ & $\begin{array}{l}\text { No significant changes in } \\
\text { self-reported knowledge } \\
\text { scores } \\
\text { Limited changes in attitudes } \\
\text { Counselling scores } \\
\text { increased between pre-test } \\
\text { and post-test }\end{array}$ \\
\hline $\begin{array}{l}\text { Zaman et al, } \\
2008^{44}\end{array}$ & Workshop & Pakistan & Healthcare workers & $\mathrm{RCT}$ & $\begin{array}{l}\text { Impact of training health workers in } \\
\text { nutrition counselling in enhancing } \\
\text { their communication skills and } \\
\text { performance, improving feeding } \\
\text { practices and reducing growth } \\
\text { faltering in children aged } \\
6-24 \text { months }\end{array}$ & $\begin{array}{l}\text { Improved communication } \\
\text { skills } \\
\text { Improved consultation } \\
\text { performance } \\
\text { Mothers able to recall } \\
\text { recommendations of health } \\
\text { workers }\end{array}$ \\
\hline $\begin{array}{l}\text { Eisenberg et al, } \\
2013^{45}\end{array}$ & Workshop & USA & $\begin{array}{l}\text { Doctors and other } \\
\text { healthcare } \\
\text { professionals }\end{array}$ & $\begin{array}{l}\text { Pre-test and } \\
\text { post-test without } \\
\text { control group }\end{array}$ & $\begin{array}{l}\text { Improving healthcare professionals } \\
\text { nutrition behaviour, personal habits } \\
\text { and their perceived ability to } \\
\text { advise overweight or obese } \\
\text { patients through the inclusion of } \\
\text { 'culinary education' in the form of } \\
\text { cooking demonstrations and } \\
\text { participatory hands-on cooking } \\
\text { workshops, combined with more } \\
\text { traditional didactic and } \\
\text { nutrition-related presentations }\end{array}$ & $\begin{array}{l}\text { Self-reported significant } \\
\text { positive changes in ability to } \\
\text { counsel obese patients } \\
\text { Changes in participants' } \\
\text { nutrition behaviours }\end{array}$ \\
\hline $\begin{array}{l}\text { Roche et al, } \\
2007^{46}\end{array}$ & $\begin{array}{l}\text { Computer-based } \\
\text { instruction }\end{array}$ & USA & Paediatric residents & RCT & $\begin{array}{l}\text { A computer-based compact disc } \\
\text { instructional programme covering } \\
\text { the nutrition topics of oral } \\
\text { rehydration therapy, calcium and } \\
\text { vitamins }\end{array}$ & $\begin{array}{l}\text { Modest improvement in } \\
\text { self-reported knowledge } \\
\text { scores after intervention } \\
\text { Positive attitudes towards } \\
\text { computer instruction after } \\
\text { intervention } \\
\text { Participants believed } \\
\text { intervention enhanced their } \\
\text { knowledge in nutrition }\end{array}$ \\
\hline $\begin{array}{l}\text { Gance-Cleveland } \\
\text { et al, } 2009^{47}\end{array}$ & Workshop & USA & Nurse practitioners & $\begin{array}{l}\text { Pre-test and } \\
\text { post-test without } \\
\text { control group }\end{array}$ & $\begin{array}{l}\text { Four-hour training session on } \\
\text { HEAT CPG to improve provider } \\
\text { behaviour and efficacy } \\
\text { Topics covered included obesity } \\
\text { prevention, behaviour } \\
\text { modifications and family }\end{array}$ & $\begin{array}{l}\text { Post-training results } \\
\text { revealed significant } \\
\text { improvement in practitioner } \\
\text { knowledge } \\
\text { Post-training results } \\
\text { revealed significant }\end{array}$ \\
\hline
\end{tabular}


Table 1 Continued

\begin{tabular}{|c|c|c|c|c|c|c|}
\hline $\begin{array}{l}\text { Author(s) and } \\
\text { year }\end{array}$ & Intervention type & $\begin{array}{l}\text { Study } \\
\text { location }\end{array}$ & Participants & Study design & $\begin{array}{l}\text { Focus of intervention/topics } \\
\text { covered }\end{array}$ & Outcomes \\
\hline & & & & & $\begin{array}{l}\text { counselling, family collaboration } \\
\text { and advising }\end{array}$ & $\begin{array}{l}\text { improvement in practitioners' } \\
\text { intent to improve behaviour } \\
\text { Post-training results } \\
\text { revealed significant } \\
\text { improvements in } \\
\text { practitioners' report of } \\
\text { increased confidence in } \\
\text { ability to address barriers }\end{array}$ \\
\hline Ray et al, $2014^{48}$ & Workshop & UK & Junior doctors & $\begin{array}{l}\text { Pre-test and } \\
\text { post-test without } \\
\text { control group }\end{array}$ & $\begin{array}{l}\text { Nutrition assessment in } \\
\text { hospitalised patients }\end{array}$ & $\begin{array}{l}\text { Significant improvement in } \\
\text { knowledge, attitudes and } \\
\text { practice scores }\end{array}$ \\
\hline $\begin{array}{l}\text { Bassichetto and } \\
\text { Réa, } 2008^{49}\end{array}$ & Workshop & Brazil & $\begin{array}{l}\text { Paediatricians and } \\
\text { nutritionists }\end{array}$ & RCT & $\begin{array}{l}\text { Training intervention to equip junior } \\
\text { doctors to run a hospital nutrition } \\
\text { awareness week to contribute to } \\
\text { the improvement in nutrition care } \\
\text { Topics covered included clinical } \\
\text { and public health nutrition, } \\
\text { organisational management and } \\
\text { leadership strategies }\end{array}$ & $\begin{array}{l}\text { Significant improvement in } \\
\text { knowledge scores after } \\
\text { intervention } \\
\text { Improvement in dietary } \\
\text { counselling after intervention }\end{array}$ \\
\hline $\begin{array}{l}\text { Dacey et al, } \\
2013^{50}\end{array}$ & Workshop & USA & $\begin{array}{l}\text { Doctors and other } \\
\text { healthcare } \\
\text { professionals }\end{array}$ & $\begin{array}{l}\text { Pre-test and } \\
\text { post-test without } \\
\text { control group }\end{array}$ & $\begin{array}{l}\text { The impact of two types of live } \\
\text { face-to-face CME programmes } \\
\text { aiming to alter participants' } \\
\text { thinking and behaviour and } \\
\text { comfort with the use of lifestyle } \\
\text { medicine } \\
\text { Topics included the history and } \\
\text { rationale for lifestyle medicine, } \\
\text { exercise medicine initiative and } \\
\text { lifestyle medicine competencies }\end{array}$ & $\begin{array}{l}\text { Improvement in the } \\
\text { perception of barriers to } \\
\text { lifestyle medicine } \\
\text { Improvement in self-reported } \\
\text { knowledge } \\
\text { Increased confidence to } \\
\text { counsel }\end{array}$ \\
\hline $\begin{array}{l}\text { Ritenbaugh et al, } \\
1996^{51}\end{array}$ & $\begin{array}{l}\text { 4-year integrated } \\
\text { nutrition curriculum }\end{array}$ & USA & $\begin{array}{l}\text { All levels of medical } \\
\text { students }\end{array}$ & Cross-sectional & $\begin{array}{l}\text { Evaluation of an integrated } \\
\text { nutrition curriculum }\end{array}$ & $\begin{array}{l}\text { Changes in knowledge } \\
\text { Students satisfied with } \\
\text { curriculum }\end{array}$ \\
\hline $\begin{array}{l}\text { Tziraki et al, } \\
2000^{14}\end{array}$ & Workshop & USA & Primary care doctors & RCT & $\begin{array}{l}\text { Training to improve the adoption of } \\
\text { a manual to guide primary care } \\
\text { practices in structuring their office } \\
\text { environment and routine visits to } \\
\text { improve nutrition screening, } \\
\text { advice/referral and follow-up for } \\
\text { cancer prevention } \\
\text { Compared the effect of training on }\end{array}$ & $\begin{array}{l}\text { Greater adoption of manual } \\
\text { recommendations among } \\
\text { practices in the training } \\
\text { group } \\
\text { Training group adhered } \\
\text { closer to diet screening } \\
\text { recommendations in the } \\
\text { manual }\end{array}$ \\
\hline
\end{tabular}




\begin{tabular}{|c|c|c|c|c|c|c|}
\hline $\begin{array}{l}\text { Author(s) and } \\
\text { year }\end{array}$ & Intervention type & $\begin{array}{l}\text { Study } \\
\text { location }\end{array}$ & Participants & Study design & $\begin{array}{l}\text { Focus of intervention/topics } \\
\text { covered }\end{array}$ & Outcomes \\
\hline & & & & & $\begin{array}{l}\text { the manual with mailing the } \\
\text { manual to practices }\end{array}$ & $\begin{array}{l}\text { Changes in office } \\
\text { environment were conducive } \\
\text { to nutrition screening and } \\
\text { dietary advice }\end{array}$ \\
\hline $\begin{array}{l}\text { Edwards and } \\
\text { Wyles, } 1999^{52}\end{array}$ & Workshop & UK & $\begin{array}{l}\text { Healthcare } \\
\text { professionals }\end{array}$ & $\begin{array}{l}\text { Pre-test and } \\
\text { post-test without } \\
\text { control group }\end{array}$ & $\begin{array}{l}\text { Effectiveness of training sessions } \\
\text { for health professionals concerning } \\
\text { folic acid in pregnancy }\end{array}$ & $\begin{array}{l}\text { Improvement in knowledge } \\
\text { after training } \\
\text { Participants enjoyed most } \\
\text { parts of the training }\end{array}$ \\
\hline $\begin{array}{l}\text { Castro et al, } \\
2013^{53}\end{array}$ & Workshop & Brazil & Doctors in the ICU & $\begin{array}{l}\text { Pre-test and } \\
\text { post-test with } \\
\text { control group }\end{array}$ & $\begin{array}{l}\text { A multifaceted nutritional } \\
\text { educational intervention on the } \\
\text { quality of nutritional therapy and } \\
\text { clinical outcomes of critically ill } \\
\text { patients }\end{array}$ & $\begin{array}{l}\text { Significant improvement in } \\
\text { participants' knowledge after } \\
\text { the intervention } \\
\text { Reduction in patients' length } \\
\text { of stay of in the ICU } \\
\text { Adequacy of nutritional } \\
\text { therapy improved } \\
\text { significantly } \\
\text { Initiating enteral nutrition } \\
\text { earlier than } 48 \text { hours more } \\
\text { commonly }\end{array}$ \\
\hline Pelto et al, $2004^{54}$ & Workshop & Brazil & Doctors & $\mathrm{RCT}$ & $\begin{array}{l}\text { Training to improve the nutrition } \\
\text { counselling behaviour of } \\
\text { physicians and caregiver retention } \\
\text { of nutrition advice using the } \\
\text { nutrition component of the WHO/ } \\
\text { UNICEF strategy of IMCI } \\
\text { Reducing growth faltering in } \\
\text { children by means of the nutrition } \\
\text { training programme }\end{array}$ & $\begin{array}{l}\text { Modest changes in } \\
\text { physician behaviour in } \\
\text { practice } \\
\text { Mother's uptake of physician } \\
\text { advice improved } \\
\text { Reduction in malnutrition } \\
\text { cases }\end{array}$ \\
\hline $\begin{array}{l}\text { Kohlmeier et al, } \\
2000^{55}\end{array}$ & $\begin{array}{l}\text { Computer-based } \\
\text { instruction }\end{array}$ & USA & $\begin{array}{l}\text { First year medical } \\
\text { students }\end{array}$ & $\begin{array}{l}\text { Pre-test and } \\
\text { post-test without } \\
\text { control group }\end{array}$ & $\begin{array}{l}\text { Evaluating students' attitudes and } \\
\text { self-efficacy in nutrition and cancer } \\
\text { and acceptability of a } \\
\text { computer-based instruction }\end{array}$ & $\begin{array}{l}\text { Significant improvement in } \\
\text { attitudes and self-efficacy } \\
\text { after intervention } \\
\text { Students generally accepted } \\
\text { computer-based instruction }\end{array}$ \\
\hline $\begin{array}{l}\text { Bjerrum et al, } \\
2012^{56}\end{array}$ & Workshop & Denmark & Nurses & $\begin{array}{l}\text { Pre-test and } \\
\text { post-test without } \\
\text { control group }\end{array}$ & $\begin{array}{l}\text { Improving nurses knowledge in } \\
\text { nutrition and their attitudes towards } \\
\text { their responsibility to providing } \\
\text { nutrition care in relation to } \\
\text { assessment and management } \\
\text { Coverage of basic nutrition } \\
\text { education, malnutrition in the } \\
\text { hospital setting }\end{array}$ & $\begin{array}{l}\text { Changes in knowledge and } \\
\text { attitudes } \\
\text { Participants felt more secure } \\
\text { in their ability to provide } \\
\text { nutrition care } \\
\text { Participants were satisfied } \\
\text { with the intervention }\end{array}$ \\
\hline
\end{tabular}

Edwards and

Castro et al

$2013^{53}$

Computer-based

Kohlmeier et

$2000^{55}$

Bjerrum et al,

$2012^{56}$ 


Author(s) and
year

year

Intervention type

Study

location

$2012^{57}$

Workshop

Denmark

Conroy et al,

Required course

USA

$2004^{58}$

Required course

SA

Israel

Endevelt et al,

Workshop

$2006^{59}$

de Fine Olivarius et al, $2005^{60}$

Schlair et al, $2012^{61}$
Seminar

Workshop
USA

USA

Participants

20

Nurses

Second year medical students

Study design

post-test without control group

Pre-test and post-test without control group

Second year medical Cross-sectional students

Primary care doctors

First year medical students

Pre-test and post-test without

\section{Focus of intervention/topics}

covered

Training programme to implement

nutritional guidelines to change

nurses' nutrition practice behaviour relating to the identification of patients' eating habits, improving patients' knowledge about appropriate food choices and number of snacks eaten between meals to risk of undernutrition in hospitalised patients

Impact of an innovative preventive medicine and nutrition curriculum

on students' confidence about addressing patients' diet and exercise patterns and on their own health habits

Identification of time slots for nutrition training for medical students

Impact of a nutrition education programme on students'

knowledge

Topics covered included nutrition and dietary recommendations for healthy people. Health risks of obesity

Improving the quality of diet recording and instruction in primary care

Diet counselling for diabetes patients using one's own diet

The feasibility and impact of a brief control group

nutrition counselling curriculum on medical students' nutrition

knowledge, confidence, attitudes and practices and their own affect the students' own nutrition

behaviour and attitudes

Topics covered were

nutrition-related counselling

confidence for patients with obesity

\section{Outcomes}

Modest changes in nutrition practice behaviour

Improvement in the eating difficulties of patients

Patients' knowledge of appropriate food choices improved

Personal dietary, exercise patterns of participants improved

Confidence in their ability to address diet and exercise in patients increased

Changes in knowledge

Students considered

nutrition curriculum to be effective

Improvement in personal dietary behaviours of participants

Changes in attitudes towards dietary counselling Significant changes in self-efficacy scores Significant changes in attitudes

Improvement in nutrition counselling competence Improvement in persona dietary habits 
Table 1 Continued

\begin{tabular}{|c|c|c|c|c|c|c|}
\hline $\begin{array}{l}\text { Author(s) and } \\
\text { year }\end{array}$ & Intervention type & $\begin{array}{l}\text { Study } \\
\text { location }\end{array}$ & Participants & Study design & $\begin{array}{l}\text { Focus of intervention/topics } \\
\text { covered }\end{array}$ & Outcomes \\
\hline & & & & & $\begin{array}{l}\text { and chronic disease and } \\
\text { understanding of simple nutrition } \\
\text { messages }\end{array}$ & \\
\hline $\begin{array}{l}\text { Scolapio et al, } \\
2008^{62}\end{array}$ & Workshop & USA & $\begin{array}{l}\text { Doctors, dieticians and } \\
\text { pharmacist }\end{array}$ & $\begin{array}{l}\text { Pre-test and } \\
\text { post-test with } \\
\text { control group }\end{array}$ & $\begin{array}{l}\text { Impact of a live continuing medical } \\
\text { education nutrition course on } \\
\text { participants' nutrition knowledge } \\
\text { and practice behaviour } \\
\text { Coverage of a variety of topics } \\
\text { including identifying methods to } \\
\text { feed patients with acute } \\
\text { pancreatitis, parenteral nutrition, } \\
\text { management of obesity and others }\end{array}$ & $\begin{array}{l}\text { Significant changes in } \\
\text { knowledge } \\
\text { Confidence in counselling } \\
\text { patients on nutrition } \\
\text { improved } \\
\text { Modest changes in practice } \\
\text { behaviours }\end{array}$ \\
\hline $\begin{array}{l}\text { Kennelly et al, } \\
2010^{63}\end{array}$ & Workshop & Ireland & GPs and nurses & $\begin{array}{l}\text { Pre-test and } \\
\text { post-test without } \\
\text { control group }\end{array}$ & $\begin{array}{l}\text { The impact of a dietetics } \\
\text { intervention on healthcare } \\
\text { professionals' knowledge in } \\
\text { nutrition and practice behaviour } \\
\text { related to the management of } \\
\text { malnutrition in hospitalised patients } \\
\text { and the acceptability of the } \\
\text { educational intervention }\end{array}$ & $\begin{array}{l}\text { Significant changes in } \\
\text { knowledge } \\
\text { Modest changes in practice } \\
\text { behaviours } \\
\text { Level of acceptance for the } \\
\text { intervention increased }\end{array}$ \\
\hline Lewis et al, $2014^{64}$ & $\begin{array}{l}\text { Internet-based } \\
\text { instruction }\end{array}$ & USA & Paediatric residents & Cross-sectional & $\begin{array}{l}\text { Evaluating paediatric trainees' } \\
\text { engagement, knowledge } \\
\text { acquisition and satisfaction with } \\
\text { nutrition modules delivered in } \\
\text { interactive and non-interactive } \\
\text { format } \\
\text { Coverage of breastfeeding } \\
\text { practices }\end{array}$ & $\begin{array}{l}\text { Significant change in } \\
\text { knowledge } \\
\text { Engagement with course } \\
\text { content increased } \\
\text { Level of satisfaction with } \\
\text { intervention increased }\end{array}$ \\
\hline $\begin{array}{l}\text { Acuña et al, } \\
2008^{65}\end{array}$ & Workshop & Brazil & $\begin{array}{l}\text { Medical and nursing } \\
\text { students }\end{array}$ & $\begin{array}{l}\text { Pre-test and } \\
\text { post-test without } \\
\text { control group }\end{array}$ & $\begin{array}{l}\text { Evaluating the effect of an } \\
\text { intensive education course given } \\
\text { to healthcare professionals and } \\
\text { students } \\
\text { Topics covered related to hospital } \\
\text { malnutrition }\end{array}$ & $\begin{array}{l}\text { Ability to diagnose } \\
\text { malnutrition improved }\end{array}$ \\
\hline $\begin{array}{l}\text { Powell-Tuck et al, } \\
1997^{66}\end{array}$ & Required course & USA & $\begin{array}{l}\text { Second year medical } \\
\text { students }\end{array}$ & $\begin{array}{l}\text { Pre-test and } \\
\text { post-test without } \\
\text { control group }\end{array}$ & $\begin{array}{l}\text { Development and inception of a } \\
\text { 7-day curriculum on diet and } \\
\text { health }\end{array}$ & $\begin{array}{l}\text { Students' feedback was } \\
\text { positive } \\
\text { Significant changes in } \\
\text { knowledge }\end{array}$ \\
\hline $\begin{array}{l}\text { Afaghi et al, } \\
2012^{67}\end{array}$ & Workshop & Iran & $\begin{array}{l}\text { Clinical year } 4 \text { and } 5 \\
\text { students }\end{array}$ & $\begin{array}{l}\text { Pre-test and } \\
\text { post-test without } \\
\text { control group }\end{array}$ & $\begin{array}{l}\text { Clinical-based case study teaching } \\
\text { to enhance clinical skills regarding } \\
\text { the role of nutrition in chronic } \\
\text { disease }\end{array}$ & $\begin{array}{l}\text { Student perceptions of the } \\
\text { adequacy of the instruction } \\
\text { were positive }\end{array}$ \\
\hline
\end{tabular}




\begin{tabular}{|c|c|c|c|c|c|c|}
\hline $\begin{array}{l}\text { Author(s) and } \\
\text { year }\end{array}$ & Intervention type & $\begin{array}{l}\text { Study } \\
\text { location }\end{array}$ & Participants & Study design & $\begin{array}{l}\text { Focus of intervention/topics } \\
\text { covered }\end{array}$ & Outcomes \\
\hline & & & & & $\begin{array}{l}\text { Topics covered included the role of } \\
\text { nutrition in chronic diseases, } \\
\text { assessment of dietary intake and } \\
\text { weight management }\end{array}$ & $\begin{array}{l}\text { Significant changes in } \\
\text { knowledge }\end{array}$ \\
\hline $\begin{array}{l}\text { Carson et al, } \\
2002^{68}\end{array}$ & Required course & USA & $\begin{array}{l}\text { Fourth year medical } \\
\text { students }\end{array}$ & $\begin{array}{l}\text { Pre-test post-test } \\
\text { with control } \\
\text { group }\end{array}$ & $\begin{array}{l}\text { The outcomes of an integrated } \\
\text { cardiovascular nutrition in the } \\
\text { fourth year of medical school at the } \\
\text { University of Texas }\end{array}$ & $\begin{array}{l}\text { Significant changes in } \\
\text { knowledge } \\
\text { Significant changes in } \\
\text { attitude } \\
\text { Self-efficacy in addressing } \\
\text { nutrition issues improved }\end{array}$ \\
\hline $\begin{array}{l}\text { Vanderpool et al, } \\
2014^{69}\end{array}$ & $\begin{array}{l}\text { Continuous medical } \\
\text { education }\end{array}$ & USA & $\begin{array}{l}\text { Paediatric } \\
\text { gastroenterology } \\
\text { residents and } \\
\text { paediatric } \\
\text { gastroenterologists }\end{array}$ & $\begin{array}{l}\text { Pre-test and } \\
\text { post-test without } \\
\text { control group }\end{array}$ & $\begin{array}{l}\text { Improving nutrition knowledge } \\
\text { acquisition and dissemination } \\
\text { Topics covered included paediatric } \\
\text { nutrition and paediatric nutrition } \\
\text { assessment }\end{array}$ & $\begin{array}{l}\text { Changes in knowledge } \\
\text { Changes in behaviour } \\
\text { Changes in patient } \\
\text { outcomes }\end{array}$ \\
\hline Duerksen, $2002^{70}$ & Clinical rotation & Canada & $\begin{array}{l}\text { Second year medical } \\
\text { students }\end{array}$ & $\begin{array}{l}\text { Pre-test and } \\
\text { post-test without } \\
\text { control group }\end{array}$ & $\begin{array}{l}\text { Assessment of hospitalised } \\
\text { patients' nutrition using the SGA }\end{array}$ & $\begin{array}{l}\text { Students correctly identified } \\
\text { malnourished patients } \\
\text { Increased confidence in } \\
\text { nutritional assessment }\end{array}$ \\
\hline Engel et al, $1997^{71}$ & $\begin{array}{l}\text { Computer-based } \\
\text { training as part of } \\
\text { family practice } \\
\text { clerkship rotation }\end{array}$ & USA & $\begin{array}{l}\text { Third year medical } \\
\text { students }\end{array}$ & $\begin{array}{l}\text { Pre-test and } \\
\text { post-test without } \\
\text { control group }\end{array}$ & $\begin{array}{l}\text { Knowledge and self-efficacy in } \\
\text { prescribing diets for patients with } \\
\text { diabetes }\end{array}$ & $\begin{array}{l}\text { Improved changes in } \\
\text { knowledge } \\
\text { Improved changes in } \\
\text { self-efficacy }\end{array}$ \\
\hline $\begin{array}{l}\text { Richards and } \\
\text { Mitchell, } 2001^{72}\end{array}$ & $\begin{array}{l}\text { Presentation by a } \\
\text { dietitian to individual } \\
\text { participants }\end{array}$ & Australia & GPs & $\begin{array}{l}\text { Pre-test and } \\
\text { post-test without } \\
\text { control group }\end{array}$ & $\begin{array}{l}\text { Presentation of a nutrition manual } \\
\text { and behaviour modification } \\
\text { strategies }\end{array}$ & $\begin{array}{l}\text { Improved confidence to } \\
\text { provide specific nutrition } \\
\text { information and dietary } \\
\text { recommendations } \\
\text { Increase in the use of the } \\
\text { nutrition manual } \\
\text { Nutrition counselling of } \\
\text { patients improved }\end{array}$ \\
\hline Kipp, $1997^{73}$ & $\begin{array}{l}\text { Computer-based } \\
\text { instruction }\end{array}$ & USA & $\begin{array}{l}\text { First year medical } \\
\text { students }\end{array}$ & $\begin{array}{l}\text { Pre-test and } \\
\text { post-test without } \\
\text { control group }\end{array}$ & $\begin{array}{l}\text { Evaluation of a CAI module on } \\
\text { food guide pyramid and dietary } \\
\text { guidelines }\end{array}$ & $\begin{array}{l}\text { Students considered CAI as } \\
\text { appropriate learning tool for } \\
\text { nutrition concepts } \\
\text { Students satisfied with } \\
\text { format } \\
\text { Changes in knowledge }\end{array}$ \\
\hline $\begin{array}{l}\text { Cooksey et al, } \\
2000^{74}\end{array}$ & $\begin{array}{l}\text { Computer-based } \\
\text { instruction }\end{array}$ & USA & $\begin{array}{l}\text { Preclinical medical } \\
\text { students }\end{array}$ & Cross-sectional & $\begin{array}{l}\text { Evaluation of series of interactive, } \\
\text { multimedia educational } \\
\text { programmes (nutrition in medicine) }\end{array}$ & $\begin{array}{l}\text { Advantages of accessibility, } \\
\text { self-paced study, } \\
\text { interactivity, immediate }\end{array}$ \\
\hline
\end{tabular}


Table 1 Continued

\section{Author(s) and}

year

Intervention type

Study

Participants

Study design

Focus of intervention/topics

covered

\section{Outcomes}

that teach the basic principles of nutritional science and application

\section{Cheatham et al,} $2002^{75}$

Computer-based

USA

$$
\text { tutorial }
$$

Kolasa et al, $1996^{76}$

Workshop

Fox, $2009^{77}$

Required course

USA
Nursing, physician assistant and physical therapy students

Dietetic students, family medicine residents and third

Pre-test and post-test without control group

\section{to cases}

Development and use of a computer-based tutorial on nutritional assessment

Cross-sectional

\section{Encouraging effective} communication with media and consumer through article preparation

Community nutrition graduate students post-test without year medical students
Pre-test and control group
Incorporation of arts as strategies for understanding and addressing community health issues feedback and tracking

students' performance were noted

Significant changes in knowledge scores

Students felt amount of content was adequate Participants found the intervention to be an interesting way to learn about current food and nutrition issues

Students recognised the incorporation of arts as a mechanism of conducting health research, advocacy, education, healing and capacity-building initiatives

ANH, artificial nutrition and hydration; CME, continuous medical education; CPG, clinical practice guideline; Gl, gastroenterology; GP, general practitioner; computer-assisted instruction; GS,

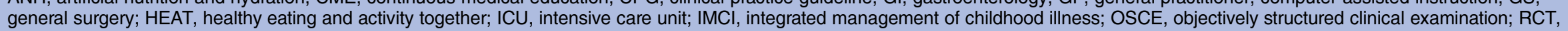
randomised controlled trial; SGA, subjective global assessment; UNICEF, United Nations Children's Fund. 
Table 2 Study designs and data collection methods

\begin{tabular}{|c|c|}
\hline Characteristic & $\begin{array}{l}\text { Frequency } \\
(\%)\end{array}$ \\
\hline \multicolumn{2}{|l|}{ Study design } \\
\hline Randomised control trials & $7(15)$ \\
\hline \multicolumn{2}{|l|}{ Quasi-experimental } \\
\hline Pre-test-post-test with control group & $6(13)$ \\
\hline Pre-test-post-test without control group & $26(57)$ \\
\hline Cross-sectional & $7(15)$ \\
\hline \multicolumn{2}{|l|}{ Methodological approach } \\
\hline Qualitative & $5(10)$ \\
\hline Quantitative & $32(70)$ \\
\hline Qualitative and quantitative & $9(20)$ \\
\hline \multicolumn{2}{|l|}{ Data collection method } \\
\hline Questionnaires/surveys only & $32(70)$ \\
\hline Observations only & $2(4)$ \\
\hline Focus group discussions only & $2(4)$ \\
\hline $\begin{array}{l}\text { Questionnaires/survey with other methods } \\
\text { (eg, interviews, observations) }\end{array}$ & $10(22)$ \\
\hline \multicolumn{2}{|l|}{ Format of intervention } \\
\hline Training programmes & $12(26)$ \\
\hline Workshops & $9(20)$ \\
\hline Required courses & $7(15)$ \\
\hline $\begin{array}{l}\text { Technology based (computer based, } \\
\text { internet based) }\end{array}$ & $11(24)$ \\
\hline Ambulatory clinical rotations & $2(4)$ \\
\hline Seminars & $1(2)$ \\
\hline Continuing medical education programmes & $4(9)$ \\
\hline \multicolumn{2}{|l|}{ Healthcare professionals $(n=22,48 \%)$} \\
\hline Doctors (GPs/primary care) & $8(36)$ \\
\hline Nurses & $5(23)$ \\
\hline $\begin{array}{l}\text { Multidisciplinary participants (eg, nurses, } \\
\text { doctors, pharmacists) }\end{array}$ & $9(41)$ \\
\hline \multicolumn{2}{|l|}{ Students $(n=24,52 \%)$} \\
\hline Undergraduate, preclinical & $14(58)$ \\
\hline Undergraduate, clinical & $5(21)$ \\
\hline Postgraduate & $5(21)$ \\
\hline
\end{tabular}

assessed using the Likert scales, anchored with statements describing attitudes.

Most questionnaires measuring behaviour changes used self-reported changes in nutrition practice behaviour. A few studies observed clinical behaviour to measure changes in nutrition practice. For example, one study in the Netherlands ${ }^{42}$ used incognito standardised patients to assess the impact of an intervention on the nutrition practice behaviour of general practitioner (GP) residents. Another study in Brazil ${ }^{54}$ measured nutrition indices (ie, wasting, stunting and underweight) of children to determine the impact of an educational intervention that aimed to improve the provision of nutrition counselling to mothers and/or caregivers by doctors.

Intervention focus, types, teaching and learning formats, duration of interventions and expected learning outcomes Only 11 studies (24\%) explicitly stated the theoretical underpinning of their interventions. These included experiential, social and cognitive learning theories as well as cognitive theory of multimedia learning. The purpose of most interventions was to improve participants' competencies (ie, knowledge, skills and attitudes) in a variety of nutrition topics (shown in table 1). Studies originating from developing countries tended to cover topics related to infant and young child feeding practices, whereas those from developed countries covered topics related to hospital malnutrition and nutritional management of chronic diseases. Most studies in which students participated aimed to increase curriculum contact hours and nutrition content. Studies involving practitioners were usually continuous medical education (CME) programmes aiming to improve knowledge, attitudes, skills and practice behaviour in specific topics such as breastfeeding practices and dietary counselling. Teaching and learning formats included lectures, problem-based learning tutorials, nutrition slogans, demonstrations, role plays, group discussions, games and video presentations. All interventions used more than one teaching and learning format except six, which were either lecture based or computer based only. ${ }^{38} 4246556469$ Almost all of the interventions used innovative teaching and learning methods. Interventions involving students were usually obligatory and lasted from 2 weeks to 4 years. Those involving professionals were generally shorter. The shortest intervention was a 1-hour intensive session for GPs and other healthcare professionals on the benefits of giving folic acid to women of child bearing age $;^{52}$ the longest were two 4-year integrated nutrition curricula for medical students. ${ }^{35} 51$ Inconsistent reporting of the length of interventions (including use of terms like credit hours) made it difficult to determine their average lengths.

\section{Context-mechanisms-outcomes configurations}

Table 3 lists the CMOs identified from the included studies. We describe here how those interacted to yield CMO configurations.

\section{Emphasising skills development instead of knowledge outcomes ('Let me be skilful')}

Researchers were often triggered to design interventions by professionals' lack of knowledge about nutrition. This was particularly true of undergraduate education, ${ }^{36} 3959646667$ where all but one ${ }^{52}$ of the interventions primarily targeting knowledge took place. Yet interventions that only aimed to improve knowledge were less likely to change practice behaviour. In four studies, for example, significant gains in knowledge did not predict practice scores, ${ }^{37}$ improve students' assessment of the nutrition status of overweight patients, ${ }^{34}$ influence behaviour change intentions ${ }^{38}$ or affect dietary counselling for mothers/caregivers of children aged 12-24 months. ${ }^{49}$ Furthermore, there were interventions, which did not significantly increase knowledge yet changed behaviour. For example, a significant improvement in diet counselling during audiotaped 


Context

Particin

Participants having inadequate

knowledge

- Participants being future and practising

healthcare professionals

- Lack of faculty to provide nutrition training at preclinical and clinical settings

- Participants being future and practising healthcare professionals

Participants being future and practising

healthcare professionals

Participants lacking time to provide nutrition care

- Lack of payment for providing preventive care

- Participants having limited access to referral sources and materials for nutrition care

- Poor investment into nutrition care

- Lack of supportive office systems to deliver nutrition care

- Separation of prevention and curative services in the healthcare system

- Inadequate instruction and syllabi for nutrition training in curricula

- Busy healthcare professionals lacking time to attend continuing education programmes in nutrition

Practising healthcare professionals

- Participants lacking appropriate tools to deliver nutrition care

- Participants' personal dietary and lifestyle habits

Participants having inadequate training in nutrition

\section{Intervention characteristics}

Emphasizing skills building instead of knowledge outcomes ('let me be skilful')

Mechanisms triggered

Being more confident

- Feeling adequately prepared

Superiors role modelling the delivery of nutrition care ('I look up to you')

Meeting the needs of potential participants of an intervention ('Ask me what I want')

Addressing structural and systemic factors to make an enabling environment ('Is my consulting room enabling?')

Incorporating technology-based education ('My computer is a learning tool') relevant tools and messages ('Give me tools')
- Sense of acceptance

- Sense of credibility

- Anticipation of being valued

- Interest

Sense of knowing the needs of participants

- Feeling comfortable to deliver nutrition care

Sense of acceptance

- Perceiving fewer barriers to the delivery of nutrition care

- Sense of recognition
Being more confident
Convenience and self-paced study

- Interactivity

- Instant feedback

- Accessibility

Removal of perceived barriers

Feeling comfortable

\section{Outcomes}

- Use of dietary counselling steps

- Self-reported confidence to counsel patients and change in counselling behaviour

- Better delivery of nutrition care in clinical settings

- Greater confidence in nutrition counselling

- Greater satisfaction with educational intervention

- Significant gains in knowledge outcomes

- Structured office environment conducive to providing nutrition-related services

- Strategies to address lack of support systems

- Encountering fewer barriers to lifestyle medicine 


\section{Context}

- Participants not routinely addressing patients' nutrition problems

- Existence of structural barriers to providing nutrition care to patients

- Poor interest in nutrition education

- Lack of confidence to deliver nutrition care

- Among future and practising healthcare professionals

Participants having inadequate

knowledge

- Among future and practising healthcare professionals

- Participants lacking training in diet counselling

Lack of patient motivation to change dietary pattern

- Lack of time

Low priority given to nutrition

- Inadequate time dedicated to nutrition

- Healthcare students

- Reported inadequate knowledge in nutrition

Multidisciplinary nature of healthcare delivery

- Cross-disciplinary nature of nutrition

\section{Intervention characteristics}

\section{Mechanisms triggered}

\section{Outcomes}

- Giving relevant advice and recommendations to patients

- Simplifying complex messages

Use of non-traditional teaching strategies ('Using the right strategy for the right job')

Improving self-efficacy ('I feel that I can do it, so I will do it')

Improving the personal health habits of healthcare professionals ('Do as I do')

Integrating nutrition content ('Add nutrition to my learning')

Adopting a multidisciplinary approach in intervention design and implementation ('Working with others')
Feeling motivated

- Feeling confident

Being more confident

Sense of being a role model

- Sense of relatedness to patients
Capture interest of participants Meet the learning needs of (ipants

participation and uptake of knowledge and skills

Relevance of learning

Accepting nutrition education

Reduction in perception of time limitations

Sense of belonging

Acceptance

- Recognising the multidisciplinary nature of nutrition healthcare delivery
- Engaging the management of malnutrition

- Engaging in exercise and dietary counselling

- Ability to counsel overweight/obese patients

- Significant changes in knowledge gains

- Positive personal health habits of participants

- Self-reported changes in practice behaviours

- Intentions to change behaviour

- Greater counselling confidence

- Intentions to change behaviour

- Positive healthy lifestyles

- Engaging in dietary assessment

- More favourable attitudes towards nutrition counselling

- Greater recognition of the relevance of nutrition education

- Increased in the number hours dedicated to nutrition

- Greater gains in cognitive outcomes

- Multidisciplinary designed programme

- Meets the needs of all participants

- Greater satisfaction 
physician-patient interactions ${ }^{43} 50$ and increased selfreported counselling behaviour and confidence ${ }^{50}$ took place without any significant increase in knowledge. In one study, Ockene et $a t^{43}$ noted that 'a large proportion ( 1.5 hour) of the entire 3 hour CME training program was devoted to the learning of counselling and dietary assessment skills'. These findings show that it is important to train skills and create learning environments that encourage the acquisition of skills in order to change healthcare professionals' nutrition care behaviour. ${ }^{78} 79$

\section{Superiors role modelling the delivery of nutrition care \\ ('I look up to you')}

A candidate theory in our published protocol, ${ }^{21}$ that healthcare professionals would be more likely to deliver nutrition care if they saw their superiors model the same behaviour, was apparent in the evidence. Seeing superiors model nutrition care led research participants to feel more confident, accepted and credible. They anticipated their actions being valued, which led them towards changing their nutrition practice. Virtual physician mentors, ${ }^{39}$ simulation of GP consultations using video clips ${ }^{42}$ physicians describing how they addressed nutrition in practice ${ }^{68}$ and role modelling by physicians in classes ${ }^{68}$ were among the interventions that provided positive role modelling.

\section{Meeting the needs of potential participants of an intervention ('Ask me what I want')}

Most interventions were modelled on the theory that education will be most successful when it is designed to meet participants' needs. ${ }^{33} \quad 34 \quad 37 \quad 48 \quad 50 \quad 52 \quad 59 \quad 62 \quad 63 \quad 67-69$ Assessment of needs identified gaps in learners' knowledge or practice behaviour, ${ }^{62}$ and how they learnt best. It informed the content, format and design of curricula. It helped select teaching and learning methods to which participants were receptive, which they found interesting and satisfying, and which led them to value their education.

\section{Addressing structural and systemic factors ('Is my consulting room enabling?')}

As well as education, interventions that improved working environments influenced participants' behaviour and helped maintain changes that had been achieved. ${ }^{57}$ Eight studies helped participants address lack of support ${ }^{33} 474869$ and systematic barriers. ${ }^{1450} 5457$ They restructured office environments to make them more conducive to providing nutrition care. ${ }^{14}$ Pelto et $a l,{ }^{54}$ for example, stated that 'structural conditions in the public health system in Pelotas provided an environment in which physicians could utilize their knowledge' (p. 360). Other researchers provided nutritional messages that busy primary care providers could deliver to patients. ${ }^{33}$ Presentations on change management and leadership ${ }^{48}$ and provision of guidelines on office organisation ${ }^{14}$ helped improve nutrition care. Collaboration between education and care delivery leaders helped remove structural and systemic barriers. ${ }^{30}$ These created working environments that were conducive to the delivery of nutrition care.

\section{Incorporating technology-based education ('My computer is} a learning tool')

Seven studies used technology to resolve challenges relating to healthcare professionals having insufficient time to attend continuing education programmes, programmes having inadequate nutrition content and faculty being unavailable to teach. ${ }^{39} \quad 42 \quad 46 \quad 55 \quad 64 \quad 68 \quad 74$ Computer-based and internet-based interventions allowed easy updating of content, ${ }^{42}$ permitted selfdirected and independent study of nutrition information, ${ }^{42}{ }^{46}$ presented content consistently, ${ }^{68}$ were accessible ${ }^{74}$ promoted interactivity ${ }^{74}$ and were convenient for participants because they were self-administered ${ }^{4268}$ and self-paced. ${ }^{74}$ These interventions led to significant gains of knowledge, ${ }^{39465564}$ positive attitudes, ${ }^{4246}$ increase in self-assessed nutrition counselling skills ${ }^{42}{ }^{55}$ and realtime practice behaviour. ${ }^{42}$ The convenience, interest and independent nature of this type of education contributed to those outcomes.

\section{Providing participants with local, practically relevant tools and messages ('Give me tools')}

Some researchers theorised that making local, practically relevant tools and messages available in practice contexts would change the behaviour of trainee healthcare professionals. The tools they provided included memorable slogans, ${ }^{33}$ simple 'key take home messages', $33 \quad 374063$ personalised nutrition messages ${ }^{33}$ and locally relevant examples. ${ }^{54}$ Researchers simplified nutrition messages, ${ }^{33}$ provided resource materials and tools to resolve problems in counselling and assessing patients, ${ }^{54} 63$ and adapted advice for local conditions. ${ }^{54}$ Those interventions helped professionals engage in specific rather than generic discussions with patients and provided advice and recommendations that patients found relevant. ${ }^{54}$ The authors of a randomised controlled trial (RCT), which improved physicians' counselling of mothers with malnourished children aged 12-24 months in Brazil, ${ }^{54}$ attributed children's improved nutritional status to this provision of locally appropriate messages and tools.

\section{Using non-traditional teaching and learning strategies ('The right strategy for the right job')}

Another theory, which guided interventions, was that non-traditional teaching and learning strategies would change professionals' behaviour. For instance, Hillenbrand and Larsen ${ }^{41}$ hypothesised that providing a series of interactive educational interventions to paediatric residents would increase their knowledge about breastfeeding and lactation problems and increase their confidence to counsel breastfeeding women. Interventions, which sometimes complemented lectures, included discussions, simulated patient cases, group work, role plays, hands-on demonstrations, group 
practice, panel discussions and case-based learning. Other interventions included problem-based learning tutorials, computer-based or web-based cases, student-led debates, self-assessment exercises and clinical case presentations. ${ }^{58} 6268$ These interventions provided practical experience and promoted active learning. They emphasised the development of skills rather than just knowledge. They engaged participants' interest and helped them assume responsibility for their own learning. These interventions caused significant changes in participants' knowledge, personal health habits, confidence to provide exercise and dietary counselling, ability to counsel obese patients and ability to manage malnutrition. Carson et $a l^{68}$ attributed the enhanced nutrition counselling skills of students in a 4-week ambulatory care rotation to their innovative combination of teaching strategies.

Improving self-efficacy ('I feel that I can do it, so I will do it') Self-efficacy is a basic tenet of Bandura's social learning theory. ${ }^{80}$ This term describes individuals' confidence in their ability to perform a task or achieve an outcome. It is a key influence on behaviour. ${ }^{80}$ Eight studies explicitly set out to improve participants' self-efficacy by increasing their confidence. They adopted strategies like role modelling by practising physicians, ${ }^{68}$ role playing using either simulated or real patients, ${ }^{41} 43 \quad 4758$ providing demonstrations and hands-on practice sessions 33414345476168 and viewing then discussing videos and web-based cases. ${ }^{43} 68$ Four each of these interventions were conducted among future healthcare professionals and practising healthcare professionals. They were effective in both settings.

\section{Improving the personal health habits of the healthcare professional ('Do as I do')}

Four interventions, which stimulated practising ${ }^{45} 60$ and health professions students ${ }^{58} 61$ to take better care of their own health, had positive outcomes. These included regular consumption of fruits and vegetables, personal awareness of calorie consumption, engagement in regular physical activity and development of culinary skills. In both settings, these led to better self-reported healthy lifestyles and self-reported ability to undertake dietary assessment, ${ }^{61}$ counselling confidence, ${ }^{45} 5861$ selfassessed knowledge ${ }^{60}$ and even treating a higher proportion of diabetic patients with diet alone. ${ }^{60}$ Healthcare professionals, who considered themselves role models for patients, felt more confident to advise patients to do as they had done. ${ }^{45} 5861$

\section{Initial and revised programme theory}

Our published protocol ${ }^{21}$ presented candidate theories and a theoretical model, which we briefly repeat here. Drawing on social cognitive theory, we postulated the following:

- Healthcare professionals' ability to deliver nutrition care is influenced by their competence, which is the outcome of a learning process, which is influenced by factors within academic environments. Those factors include the quantity and quality of nutrition content in curricula, the teaching and learning methods employed, and the extent to which learning is reinforced.

- Professionals are more likely to care for patients' nutrition if they have high self-efficacy for nutrition care and vice versa.

- Professionals' delivery of nutrition care is a behaviour demonstrated in the social context of workplaces, which is influenced by observing and modelling the behaviours, attitudes and emotional reactions of others (eg, superiors). ${ }^{81}$ It is also influenced by the structural determinants of behaviours such as the workplace settings themselves (eg, hospital/community, emergency/paediatric/general ward), job descriptions/role, time and availability of other staff to undertake particular roles.

The review process described above examined those theories, which led us to revise, add components to and broaden our theoretical model (shown in figure 2). 'Outcomes', in realist terminology, can be short, medium and long terms. ${ }^{82}$ We have added a hierarchy of outcomes to our theoretical model.

The items in the model are inter-related as opposed to operating in isolation from one another. They do not operate in a linear fashion. Several context-mechanismoutcome configurations could be generated from the data. For instance, assessments of needs identify knowledge, skills and attitude gaps and other educational needs of potential participants. The outcome of the needs assessments informs the design of the educational intervention as well as its characteristics. It informs what kind of characteristics or strategies the intervention should adopt in order to realise the desired outcome. These strategies could include improving the personal health habits of healthcare professionals, adopting technology-based education, improving skills development, adopting innovative teaching and learning strategies, role modelling and others. These generate mechanisms (not indicated in the diagram) such as interest, receptivity and acceptance, which generate short-term outcomes such as improved knowledge, attitude, skills, self-efficacy, values and personal habits. The immediate and short-term outcomes may act as mechanisms to bring about change in nutrition practice behaviour (medium-term outcome). Doctors and other healthcare professionals may change their nutrition practice behaviour as a result of having adequate knowledge, skills, attitudes, confidence and self-efficacy. A change in nutrition practice behaviour will mean increased delivery of nutrition care to patients, which may result in the long-term goal of improved clinical outcomes (long-term outcomes) of patients. However, these outcomes can best be enhanced and maintained if there is an enabling healthcare setting (context). This could be realised by enhancing certain 


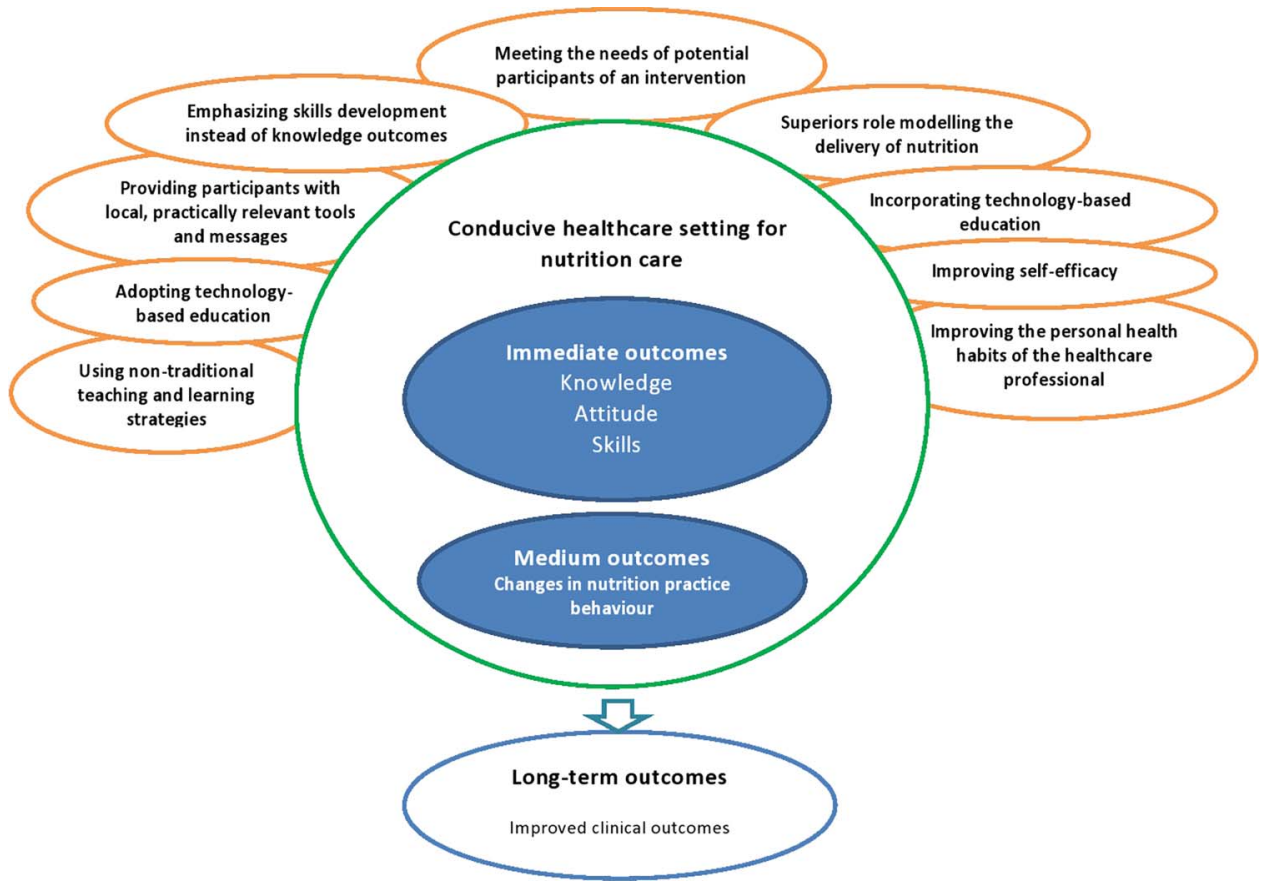

Figure 2 Revised theoretical model or programme theory.

conditions/contexts such as restructuring the healthcare system, removing structural and systemic barriers, adopting favourable policies for nutrition care, providing appropriate tools to deliver nutrition care, investing more in preventive care and providing an office that makes it easier to provide nutrition care. Providing an enabling healthcare setting was central to all of the CMO configurations identified.

We present in table 4 a summary of the characteristics of interventions in accordance with what works, for whom and under what conditions.

\section{Measurement issues}

The ultimate aim of health education is to improve health outcomes. Few studies have, however, even tried to show improvements in patients' health because it is very difficult to do. Authors acknowledged that this limited the conclusions they could draw from their evidence, ${ }^{62}$ which meant that they could often only speculate on how their interventions might affect patients' health. The impact of educational interventions is often ranked according to its position in Miller's pyramid of assessment. ${ }^{83}$ Some studies achieved the highest levelthe performance level-which is most likely to impact patient outcomes. They did so by directly observing the delivery of nutrition care in clinical settings, ${ }^{14} 41444954$ recording videos of doctors counselling patients, ${ }^{14}$ auditing charts ${ }^{40} 65 \quad 68$ and using incognito simulated patients. ${ }^{42}$ Most studies were at lower levels of the pyramid. For example, they assessed participants' reported changes in practice behaviours by means of self-administered surveys. As observed by the authors of one such study, ${ }^{58}$ reliance on students' self-reported confidence in counselling rather than an objective measure of counselling skills (such as an objectivestructured clinical examination) limits the generalisability of the findings. Schlair et $a \ell^{61}$ acknowledged the potential for social desirability bias in self-reports. While self-report would be invalid evidence in a systematic review or meta-analysis, it is safer to use it in realist synthesis, which aims to produce progressively more refined theories of change rather than incontrovertible evidence.

For future studies, Scolapio et $a l^{62}$ suggested that 'harder' data could be obtained using patient surveys and chart reviews, or having participants give specific examples of improved patient outcome that were directly linked to competences they had acquired from educational interventions. Our review shows the need for future studies to explore innovative ways of collecting this information. ${ }^{62}$

\section{DISCUSSION}

There is increasing pressure for medical education to be socially accountable. ${ }^{84-86}$ This research may be seen as socially responsive because it arose out of a pressing health need in sub-Saharan Africa: improvement of the competencies of doctors and other healthcare professionals in order to deliver effective nutrition care. Our study provided practical guidance to educators trying to meet this need in Africa and elsewhere by showing the importance of moving education for nutrition care beyond the simple acquisition of knowledge.

The CMO configurations identified in this realist review are preliminary and non-exhaustive and should be considered as a set of generic hypotheses derived 
Table 4 Overview of what works, for whom, under what circumstances and to achieve what

What works
Choosing interventions, which are educationally and clinically relevant to the needs of
Adopting appropriate teaching and learning techniques
Building on self-efficacy and confidence through role modelling
Emphasizing skills development rather than pure knowledge gains
Improving the personal lifestyle habits of healthcare professionals
Removing systemic barriers and restructuring healthcare systems to make healthcare settings
more enabling
Using practical, relevant tools
Using information and communications technology (computer-based education)
Doctors and other practising healthcare professionals
Students of the health professions
For whom
Within a multidisciplinary approach to nutrition education and care
Supported by educational and care delivery leaders
Where nutrition care is recognised as an important component of
Care delivery systems
Curricula
Where healthcare systems are structured to be conducive to the practice of nutrition care
Educational and clinical outcomes

from the best available evidence. Nonetheless, they provide information to policymakers about what may improve the nutrition practice behaviour of healthcare professionals, how, under what conditions and in what settings. Our review has identified a set of conditions that facilitate the success of interventions in varied contexts.

A key finding of this review is that improving the skills, self-efficacy and attitudes of learners by adopting appropriate teaching and learning strategies is critical to the success of nutrition education interventions. Improving learners' skills and attitudes provides them with confidence and a sense of enactive mastery of the specific tasks they have to perform. Role modelling of the delivery of nutrition care by superiors, providing appropriate physical space in which to deliver nutrition care and adopting favourable policies are important because they increase professionals' sense of being accepted, credibility, relatedness and assurance.

Our analysis shows that planners of educational interventions would be well advised to assess potential participants' needs and interests. Computer-based education presents new opportunities for course designers and planners. Already considered as a potentially efficient form of teaching and learning in the health professions, ${ }^{46} 87-89$ this presents novel ways of incorporating nutrition content into healthcare professional curricula. Given that healthcare professionals say they have too little time to attend training programmes and provide nutrition care, the convenience of computer-based and internet-based education has potential to overcome barriers to learning.

The main strengths of our review were its integrative nature and our use of realist synthesis methodology, which allowed for practical theories to be generated for future testing and implementation. However, the review had limitations. One is that we did not consult individual experts in the field when we developed our initial model. Had we done that, we might have included more candidate theories. We also acknowledge the interpretive and subjective nature of qualitative research and the likelihood that a different team of researchers might have arrived at different candidate programme theories. We acknowledge that the model shown in figure 2 is but one of several possible interpretations, as is typical of the models that emerge from realist synthesis. We acknowledge limitations in the evidence base. The synthesis that results from any review is only as good as the primary studies it is able to include. Many of the primary studies provided limited, superficial descriptions of their educational interventions. This made it difficult for us to test all components of our candidate theories and to provide rich descriptions of some of the mechanisms that were identified. As has been found by other reviewers in medical education, ${ }^{22} 2930$ this review was limited by a lack of descriptions of the contexts of the intervention, implementation processes and mechanisms.

Other limitations included the unavailability of the full text of seven studies. ${ }^{90-96}$ While it is a limitation, realist synthesis is less dependent on the inclusion of complete sets of studies than, for example, traditional systematic reviews. ${ }^{82}$ So, it may limit the scope of our findings but does not invalidate them. While the backbone of meta-analysis and traditional systematic review is aggregation, realist synthesis refines theories by obtaining a rich (rather than necessarily complete) evidence base of reports of how interventions generate certain pattern of outcome. ${ }^{82}$ We also consider as a limitation the delay in preparing the review for publication after the end of the search in December 2014. During this period, new studies might have been published, the inclusion of which may enrich further our findings. 
Finally, initial screening by just one author might be seen as a limitation, but we found such high consistency between that author's judgement and a second author in a pilot phase of the project that we judged single screening to make the best use of the inevitably limited resources in the country, where the research was conducted.

We conclude that it has been possible to assemble, from a heterogeneous database, some patterns in the links between CMOs that are consistent enough to guide the practice of nutrition education. Our findings have refined some existing candidate theories, which researchers, also, apply to their work on nutrition education.

\section{Author affiliations}

${ }^{1}$ Department of Health Professions Education and Innovative Learning, School of Medicine and Health Sciences, University for Development Studies, Tamale, Ghana

${ }^{2}$ Department of Educational Development \& Research, Faculty of Health, Medicine and Life Sciences, Maastricht University, Maastricht,

The Netherlands

${ }^{3}$ Department of Community Nutrition, School of Allied Health Sciences, University for Development Studies, Tamale, Ghana

${ }^{4}$ Department of Health Services Research, Institute of Psychology, Health and Society, University of Liverpool, Liverpool, UK

Acknowledgements The authors wish to thank MrFuseini Abdulai Braimah, senior library assistant, School of Medicine and Health Sciences, University for Development Studies, Ghana for his support in helping to retrieve full texts of some of the included studies.

Contributors VM and TD were responsible for the conception and design of the study. VM was principally responsible for searching, sourcing and initial screening of studies. VM, MGC and TD further screened studies based on abstracts. Quality assessment was performed by VM, AJJAS, FS and MGC. VM was responsible for data extraction, synthesis and interpretation of the data and drafting of the manuscript. AJJAS, TD, FS, MGC and PA contributed to interpretation of the data and revision of the article. All authors approved the article for publication.

Funding This research received no specific grant from any funding agency in the public, commercial or not-for-profit sectors.

Competing interests None declared.

Provenance and peer review Not commissioned; externally peer reviewed.

Data sharing statement VM had full access to all the data in the study and takes responsibility for the integrity of the data and the accuracy of the data analysis.

Open Access This is an Open Access article distributed in accordance with the Creative Commons Attribution Non Commercial (CC BY-NC 4.0) license, which permits others to distribute, remix, adapt, build upon this work noncommercially, and license their derivative works on different terms, provided the original work is properly cited and the use is non-commercial. See: http:// creativecommons.org/licenses/by-nc/4.0/

\section{REFERENCES}

1. Pearson TA, Blair SN, Daniels SR, et al. AHA guidelines for primary prevention of cardiovascular disease and stroke: 2002 update consensus panel guide to comprehensive risk reduction for adult patients without coronary or other atherosclerotic vascular diseases American Heart Association Science Advisory and Coordinating Committee. Circulation 2002;106:388-91.

2. Bantle JP, Wylie-Rosett J, Albright AL, et al., American Diabetes Association. Nutrition recommendations and interventions for diabetes: a position statement of the American Diabetes Association. Diabetes Care 2008;31(Suppl 1):S61-78.

3. Goldstein LB, Adams R, Alberts MJ, et al., American Heart Association/American Stroke Association Stroke Council; Atherosclerotic Peripheral Vascular Disease Interdisciplinary Working Group; Cardiovascular Nursing Council, et al. Primary prevention of ischemic stroke: a guideline from the American Heart Association/American Stroke Association Stroke Council: cosponsored by the Atherosclerotic Peripheral Vascular Disease Interdisciplinary Working Group; Cardiovascular Nursing Council; Clinical Cardiology Council; Nutrition, Physical Activity, and Metabolism Council; and the Quality of Care and Outcomes Research Interdisciplinary Working Group: The American Academy of Neurology affirms the value of this guideline. Stroke 2006;37:1583-633.

4. United Nations Children's Fund. Improving child nutrition: the achievable imperative for global progress. New York: United Nations Children's Fund, 2013:1-124.

5. Kopelman P, Lennard-Jones J. Nutrition and patients: a doctor's responsibility. Clin Med (Lond) 2002;2:391-4.

6. Council GM. Tomorrow's doctors: outcomes and standards for undergraduate medical education. Manchester, UK: General Medical Council, 2009.

7. Abid A, Galuska D, Khan L, et al. Are healthcare professionals advising obese patients to lose weight? A trend analysis. MedGenMed 2004;7:10.

8. Tsai AG, Wadden TA. Treatment of obesity in primary care practice in the United States: a systematic review. J Gen Intern Med 2009;24:1073-9.

9. Abramson S, Stein J, Schaufele M, et al. Personal exercise habits and counseling practices of primary care physicians: a national survey. Clin J Sport Med 2000;10:40-8.

10. Huang J, Yu H, Marin E, et al. Physicians' weight loss counseling in two public hospital primary care clinics. Acad Med 2004;79:156-61.

11. Laschinger HKS, Tresolini CP. An exploratory study of nursing and medical students health promotion counselling self-efficacy. Nurse Educ Today 1999;19:408-18.

12. Jay M, Gillespie C, Ark T, et al. Do internists, pediatricians, and psychiatrists feel competent in obesity care? J Gen Intern Med 2008;23:1066-70

13. Foster GD, Wadden TA, Makris AP, et al. Primary care physicians' attitudes about obesity and its treatment. Obes Res 2003;11:1168-77.

14. Tziraki C, Graubard $\mathrm{BI}$, Manley $\mathrm{M}$, et al. Effect of training on adoption of cancer prevention nutrition-related activities by primary care practices: results of a randomized, controlled study. J Gen Intern Med 2000;15:155-62.

15. McLaren DS. Nutrition in medical schools: a case of mistaken identity. Am J Clin Nutr 1994;59:960-3.

16. Weinsier RL. National Dairy Council Award for Excellence in Medical/Dental Nutrition Education Lecture, 1995: medical-nutrition education-factors important for developing a successful program. Am J Clin Nutr 1995;62:837-40.

17. Gershoff SN. National Dairy Council Award for Excellence in Medical/Dental Nutrition Education Lecture, 1996: nutrition education —success or failure? Am J Clin Nutr 1996;64:809-12.

18. Ball LE, Hughes RM, Leveritt MM. Nutrition in general practice: role and workforce preparation expectations of medical educators. Aust $J$ Prim Health 2010;16:304-10.

19. Mechanic $D$. Social research in health and the American sociopolitical context: the changing fortunes of medical sociology. Soc Sci Med 1993;36:95-102.

20. Sunguya BF, Poudel KC, Mlunde LB, et al. Nutrition training improves health workers' nutrition knowledge and competence to manage child undernutrition: a systematic review. Front Public Health 2013;1:37.

21. Mogre V, Scherpbier A, Dornan T, et al. A realist review of educational interventions to improve the delivery of nutrition care by doctors and future doctors. Syst Rev 2014;3:148.

22. Wong G, Greenhalgh T, Pawson R. Internet-based medical education: a realist review of what works, for whom and in what circumstances. BMC Med Educ 2010;10:12.

23. Pawson R, Greenhalgh T, Harvey G, et al. Realist synthesis: an introduction: ESRC Research Methods Programme, University of Manchester RMP: Methods Paper 2, 2004. http://www.ccsr.ac.uk/ methods/ publications/documents/RMPmethods2.pdf

24. McCormack B, Rycroft-Malone J, DeCorby K, et al. A realist review of interventions and strategies to promote evidence-informed healthcare: a focus on change agency. Implement Sci 2013;8:107.

25. Pawson R. Evidence-based policy: a realist perspective. Thousand Oaks (CA): Sage, 2006. 
26. Pawson R, Greenhalgh T, Harvey G, et al. Realist review-a new method of systematic review designed for complex policy interventions. J Health Serv Res Policy 2005;10(Suppl 1):21-34.

27. Westhorp G, Walker B, Rogers $\mathrm{P}$, et al. Enhancing community accountability, empowerment and education outcomes in low and middle-income countries: a realist review: EPPI-centre, social science research unit, institute of education. London: University of London, 2014.

28. Pluye P, Robert E, Cargo M, et al. Proposal: a mixed methods appraisal tool for systematic mixed studies reviews. Montréal: McGill University, 2011.

29. Yardley S, Cottrell E, Rees E, et al. Modelling successful primary care for multimorbidity: a realist synthesis of successes and failures in concurrent learning and healthcare delivery. BMC Fam Pract 2015;16:23.

30. Jones AC, Shipman SA, Ogrinc G. Key characteristics of successful quality improvement curricula in physician education: a realist review. BMJ Qual Saf 2015;24:77-88.

31. Steinert $\mathrm{Y}$, Mann K, Centeno A, et al. A systematic review of faculty development initiatives designed to improve teaching effectiveness in medical education: BEME Guide No. 8. Med Teach 2006;28:497-526

32. Shamseer L, Moher D, Clarke M, et al., PRISMA-P Group. Preferred reporting items for systematic review and meta-analysis protocols (PRISMA-P) 2015: elaboration and explanation. BMJ 2015;349: g7647.

33. Levy J, Harris J, Darby $\mathrm{P}$, et al. The primary care nutrition training program: an approach to communication on behavior change. Health Promot Pract 2011:12:761-8.

34. Carson JAS. Pocket tape measure for waist circumference: training medical students and residents on a simple assessment of body composition. J Nutr 2003;133:547S-9S.

35. Taren DL, Thomson CA, Koff NA, et al. Effect of an integrated nutrition curriculum on medical education, student clinical performance, and student perception of medical-nutrition training. Am J Clin Nutr 2001;73:1107-12.

36. Buckley KM. Evaluation of classroom-based, web-enhanced, and web-based distance learning nutrition courses for undergraduate nursing. J Nurs Educ 2003;42:367-70.

37. Ray S, Udumyan R, Rajput-Ray M, et al. Evaluation of a novel nutrition education intervention for medical students from across England. BMJ Open 2012;2:e000417.

38. Ke LS, Chiu TY, Hu WY, et al. Effects of educational intervention on nurses' knowledge, attitudes, and behavioral intentions toward supplying artificial nutrition and hydration to terminal cancer patients. Support Care Cancer 2008;16:1265-72.

39. Buchowski MS, Plaisted C, Fort J, et al. Computer-assisted teaching of nutritional anemias and diabetes to first-year medical students. Am J Clin Nutr 2002;75:154-61.

40. Puoane T, Sanders D, Ashworth A, et al. Training nurses to save lives of malnourished children. Curationis 2006;29:73-8.

41. Hillenbrand KM, Larsen PG. Effect of an educational intervention about breastfeeding on the knowledge, confidence, and behaviors of pediatric resident physicians. Pediatrics 2002;110:e59.

42. Maiburg BH, Rethans JJ, Schuwirth LW, et al. Controlled trial of effect of computer-based nutrition course on knowledge and practice of general practitioner trainees. Am J Clin Nutr 2003;77(4 Suppl):1019S-24S.

43. Ockene JK, Ockene IS, Quirk ME, et al. Physician training for patient-centered nutrition counseling in a lipid intervention trial. Pre Med 1995;24:563-70.

44. Zaman S, Ashraf RN, Martines J. Training in complementary feeding counselling of healthcare workers and its influence on maternal behaviours and child growth: a cluster-randomized controlled trial in Lahore, Pakistan. J Health Popul Nutr 2008;26:210-22.

45. Eisenberg DM, Miller AM, McManus K, et al. Enhancing medical education to address obesity: "See one. Taste one. Cook one. Teach one.". JAMA Intern Med 2013;173:470-2.

46. Roche PL, Ciccarelli MR, Gupta SK, et al. Multi-school collaboration to develop and test nutrition computer modules for pediatric residents. J Am Diet Assoc 2007;107:1586-9.

47. Gance-Cleveland B, Sidora-Arcoleo K, Keesing $\mathrm{H}$, et al. Changes in nurse practitioners' knowledge and behaviors following brief training on the healthy eating and activity together (HEAT) guidelines. $J$ Pediatr Health Care 2009;23:222-30.

48. Ray S, Laur C, Douglas P, et al. Nutrition education and leadership for improved clinical outcomes: training and supporting junior doctors to run 'Nutrition Awareness Weeks' in three NHS hospitals across England. BMC Med Educ 2014;14:109.

49. Bassichetto KC, Réa MF. Infant and young child feeding counseling: an intervention study. J Pediatr (Rio J) 2008;84:75-82.
50. Dacey M, Arnstein F, Kennedy MA, et al. The impact of lifestyle medicine continuing education on provider knowledge, attitudes, and counseling behaviors. Med Teach 2013;35:e1149-e56.

51. Ritenbaugh CK, Thomson CA, Taren D, et al. Nutrition curriculum in medical education: an integrated and comprehensive approach. Teach Learn Med 1996;8:102-10.

52. Edwards L, Wyles D. The folic acid message - can training make a difference? J Hum Nutr Diet 1999;12:317-26.

53. Castro MG, Pompilio CE, Horie LM, et al. Education program on medical nutrition and length of stay of critically ill patients. Clin Nutr 2013;32:1061-6.

54. Pelto GH, Santos I, Gonçalves $\mathrm{H}$, et al. Nutrition counseling training changes physician behavior and improves caregiver knowledge acquisition. J Nutr 2004;134:357-62.

55. Kohlmeier M, Althouse L, Stritter F, et al. Introducing cancer nutrition to medical students: effectiveness of computer-based instruction. Am J Clin Nutr 2000;71:873-7.

56. Bjerrum M, Tewes M, Pedersen P. Nurses' self-reported knowledge about and attitude to nutrition - before and after a training programme. Scand J Caring Sci 2012;26:81-9.

57. Pedersen PU, Tewes M, Bjerrum M. Implementing nutritional guidelines-the effect of systematic training for nurse nutrition practitioners. Scand J Caring Sci 2012;26:178-85.

58. Conroy MB, Delichatsios HK, Hafler JP, et al. Impact of a preventive medicine and nutrition curriculum for medical students. Am J Prev Med 2004:27:77-80.

59. Endevelt R, Shahar DR, Henkin Y. Development and implementation of a nutrition education program for medical students: a new challenge. Educ Health (Abingdon) 2006;19:321-30.

60. de Fine Olivarius N, Palmvig B, Andreasen AH, et al. An educational model for improving diet counselling in primary care: a case study of the creative use of doctors' own diet, their attitudes to it and to nutritional counselling of their patients with diabetes. Patient Educ Couns 2005;58:199-202.

61. Schlair S, Hanley K, Gillespie C, et al. How medical students' behaviors and attitudes affect the impact of a brief curriculum on nutrition counseling. J Nutr Educ Behav 2012;44:653-7.

62. Scolapio JS, Dibaise JK, Schwenk WF II, et al. Advances and controversies in clinical nutrition: the education outcome of a live continuing medical education course. Nutr Clin Pract 2008;23:90-5

63. Kennelly S, Kennedy NP, Rughoobur GF, et al. An evaluation of a community dietetics intervention on the management of malnutrition for healthcare professionals. J Hum Nutr Diet 2010;23:567-74.

64. Lewis KO, Frank GR, Nagel R, et al. Pediatric trainees' engagement in the online nutrition curriculum: preliminary results. BMC Med Educ 2014:14:190.

65. Acuña K, Pires C, Santos G, et al. Detection of nosocomial malnutrition is improved in Amazon region by a standard clinical nutrition education program. Nutr Hosp 2008;23:60-7.

66. Powell-Tuck J, Summerbell C, Holsgrove G, et al. Four years' experience of an undergraduate medical nutrition course. J $R$ Soc Med 1997;90:67-72.

67. Afaghi A, Hai Agha Mohamadi AA, Ziaee A, et al. Effect of an integrated case-based nutrition curriculum on medical education at Qazvin University of Medical Sciences, Iran. Glob J Health Sci 2012;4:112-17.

68. Carson JAS, Gillham MB, Kirk LM, et al. Enhancing self-efficacy and patient care with cardiovascular nutrition education. Am J Prev Med 2002;23:296-302.

69. Vanderpool C, Lin HC, Scheimann A. NASPGHAN Nutrition University as a model for continuing education within pediatric nutrition. J Pediatr Gastroenterol Nutr 2014:58:469-71.

70. Duerksen DR. Teaching medical students the subjective global assessment. Nutrition 2002:18:313-15.

71. Engel SS, Crandall J, Basch CE, et al. Computer-assisted diabetes nutrition education increases knowledge and self-efficacy of medical students. Diabetes Educ 1997;23:545-9.

72. Richards D, Mitchell G. Insight. GPs and nutrition: what they want and how they want it. A GP nutrition education project. Aust J Nutr Diet 2001;58:56-9.

73. Kipp DE. Technological methods in nutrition education. Developing interactive computerized modules accessible on the World Wide Web for medical students. Top Clin Nutr 1997;12:38-44.

74. Cooksey K, Kohlmeier M, Plaisted C, et al. Getting nutrition education into medical schools: a computer-based approach. Am J Clin Nutr 2000;72:868S-76S.

75. Cheatham M, Boosalis MG, Boissonneault GA. Use of a computer tutorial on nutritional assessment by three different groups of health professions students. J Allied Health 2002;31:252-5. 
76. Kolasa KM, Elesha-Adams M, Patton DD. When a reporter calls: media training to teach nutrition education. Top Clin Nutr 1996;11:75-80.

77. Fox AL. Evaluation of a pilot arts and health module in a graduate community nutrition program. Can J Diet Pract Res 2009;70:81-6.

78. Ockene JK, Kristeller J, Goldberg R, et al. Increasing the efficacy of physician-delivered smoking interventions. J Gen Intern Med 1991;6:1-8.

79. Bandura A, McClelland DC. Social learning theory. Englewood Cliffs (NJ): Prentice-Hall, 1977.

80. Bandura A. Self-efficacy: the exercise of control. Macmillan, 1997.

81. Bandura A. Social cognitive theory: an agentic perspective. Annu Rev Psychol 2001;52:1-26.

82. Westhorp G, Walker B, Rogers P. Under what circumstances does enhancing community accountability and empowerment improve education outcomes, particularly for the poor? A realist synthesis protocol. London: EPPI-Centre, Social Science Research Unit, Institute of Education, University of London, 2012.

83. Miller GE. The assessment of clinical skills/competence/ performance. Acad Med 1990;65:S63-7.

84. Lindgren $\mathrm{S}$, Karle $\mathrm{H}$. Social accountability of medical education: aspects on global accreditation. Med Teach 2011;33:667-72.

85. Boelen C, Woollard R. Social accountability: the extra leap to excellence for educational institutions. Med Teach 2011;33 614-19.

86. Boelen C, Woollard B. Social accountability and accreditation: a new frontier for educational institutions. Med Educ 2009;43:887-94.

87. Devitt $P$, Palmer E. Computer-aided learning: an overvalued educational resource? Med Educ 1999;33:136-9.
88. Carr MM, Reznick RK, Brown DH. Comparison of computer-assisted instruction and seminar instruction to acquire psychomotor and cognitive knowledge of epistaxis management. Otolaryngol Head Neck Surg 1999;121:430-4.

89. D'Alessandro DM, Kreiter CD, Erkonen WE, et al. Longitudinal follow-up comparison of educational interventions: multimedia textbook, traditional lecture, and printed textbook. Acad Radiol 1997;4:719-23.

90. Deen D, Karp R, Lowell B. A mini-fellowship in clinical nutrition for primary care physicians. J Cancer Educ 2000;15:134-6.

91. Heimburger DC, Ullmann DO, Ramsey MJ, et al. Dietary habits of first-year medical students assessed during clinical nutrition course. Nutrition 1994;10:214-20.

92. Hodgson CS, Wilkerson L, Go VL. Changes in nutrition knowledge among first- and second-year medical students following implementation of an integrated nutrition curriculum. J Cancer Educ 2000;15:144-7.

93. Kolasa KM, Jobe AC, Miller MG, et al. Teaching medical students cancer risk reduction nutrition counseling using a multimedia program. Fam Med 1999;31:200-4.

94. Edwards M. Nutrition education for medical students: 4th year transition to residency for primary care (1020.3). The FASEB Journal 2014;28(1 Suppl):1020.3.

95. Carson JAS. Impact of integrating cardiovascular nutrition in an ambulatory care rotation on the knowledge, attitudes, self-efficacy and patient care practices of fourth year medical students. Doctoral dissertation. University of Texas-Austin, 2000

96. Baker K, Olfert M. Incorporating nutrition education through applied, hands-on culinary elective in medical school training (1020.2). FASEB J 2014;28(1 Suppl):1020.2. 